\title{
Effect of Nitrogen Fertilization Rates on Wheat Grown under Drip Irrigation System
}

\author{
Rekaby, S. A. ${ }^{1}$; M. A. Eissa ${ }^{2}$; S. A. Hegab ${ }^{1}$ and H. M. Ragheb ${ }^{2}$ \\ ${ }^{1}$ Department of Soils and Water, Faculty of Agriculture, Al-Azhar University, Assiut, Egypt \\ ${ }^{2}$ Department of Soils and Water, Faculty of Agriculture, Assiut University, Assiut, Egypt
}

Received on: $22 / 5 / 2016$

Accepted for publication on: 25/5/2016

\begin{abstract}
Application of nitrogen $(\mathrm{N})$ fertilizer is one of the most important actions that increases grain yield and improves grain quality in winter wheat (Triticum aestivum L.) production. Presently, there are a large number of investigations in the field on different nitrogen fertilizer application regimes. However, there is little information available about the optimum level of $\mathrm{N}$ for drip irrigated wheat. Filed experiments in Randomized Complete Block Design (RCBD) conducted to study the response of drip irrigated wheat to three levels of $N(120,180$, and 240 $\mathrm{kg} \mathrm{N} \mathrm{ha}{ }^{-1}$ ). The field experiments were carried out at the Agricultural Experimental Station farm of the Faculty of Agriculture, Assiut University, Egypt during the two successive growth seasons of 2013/14 and 2014/2015. The application of $\mathrm{N}$ significantly $(P<0.05)$ enhanced the growth of drip irrigated wheat. The highest rate of nitrogen increased the uptake of $\mathrm{N}, \mathrm{P}$, and $\mathrm{K}$ by 61,75 , and $57 \%$ compared to the lowest treatment. Increasing rate of nitrogen to $240 \mathrm{~kg} \mathrm{~N}$ per hectare increased the Water Use Efficiency (WUE) by 34 and 22\% in the first and second season, respectively, compared to $\mathrm{N}_{120}$ treatment. The number of spike per $\mathrm{m}^{2}$, number of grains per spike, and grain weight per spike of wheat were affected significantly $(P<0.05)$ by $\mathrm{N}$ treatments. The application of $\mathrm{N}_{240}$ increased the wheat grain yield by 34 and $22 \%$ in the first and second season, respectively, compared to $\mathrm{N}_{120}$. Based on the obtained results, it is recommended to fertilize drip irrigated wheat by $240 \mathrm{~kg} \mathrm{~N}$ per hectare.
\end{abstract}

Keywords: Drip irrigation, wheat, urea, nutrients uptake, water use efficiency, yield

\section{Introduction}

In arid and semi-arid regions, water scarcity is the main yield limiting factor, where it is difficult to apply full crop water requirements to sustain maximal growth and yield. Therefore it is very important to determine how to maintain optimum crop yields under water deficit conditions. Recently, this has stimulated the researchers to find new irrigation technology, systems, and irrigation strategies to improve water and nutrients use efficiency. In modern irrigation systems, water and nutrients are supplied simultaneously (fertiga- tion), mainly by drip irrigation devices (Bar-Yosef, 1999) which considered to be the most effective method to supply water and nutrients to plants (Zhang et al., 2013). Drip irrigation has several advantages over traditional methods, such as better water and nutrients management (Eissa et al., 2013), increasing crops yields and quality (Aujla et al., 2007; Eissa et al., 2013), and greater increases in water and nutrients use efficiency (Al-Omran et al. 2005; Mathieu et al., 2007; Eissa et al., 2013; Liang et al., 2014). Fertigation is an effective tool to control placement, 
timing, and the type of fertilizer needed according to the soil fertility status and the growth stage of crop. When combined with an efficient irrigation system, both nutrients and water can be manipulated and managed to obtain the maximum possible yield of marketable production from a given quantity of these inputs, moreover, minimize environmental pollution (Schumann et al., 2009; Melgar et al., 2010; Eissa et al., 2013; Liang et al., 2014).

Agriculture soil resources in Egypt are limited, only $3.5 \%$ of the total area is agricultural, whereas desert occupies $96 \%$ of total area. Water scarcity is one of the major problems for crop production in Egypt, this is needs to reduce the consumption of water in irrigation by developing new technologies and methods that can be help full to utilize this precious input in an effective way. Agriculture in Egypt is almost entirely dependent on irrigation and the single main source of water is the Nile.

Wheat (Triticum aestivum L.) is one of the most important cereal crops of the world on account of its wide adaptability to different agroclimatic conditions and different soils. Among major cereals, wheat ranks first in area and production at the global level and it contributes more calories and proteins to the world's human diet than any other cereals. It is the main staple food of nearly 35 per cent of the world population. The total cultivated area of wheat in the world is 240.00 million hectares with an annual production of 713 million tonnes, with an average productivity of $2717 \mathrm{kgha}^{-1}$ (FAOS-
TAT, 2014). In Egypt, wheat is the first most important food crop; with a cultivated area of 1.3 million hectares in 2013 which produced 8.53 million tones (FAOSTAT, 2014). Wheat production in Egypt represents $54 \%$ of the total consumption and imports the reset amount yearly (FAOSTAT, 2014).

Recently a great attention of several investigations has been directed to increase the productivity of wheat to minimize the gap between the Egyptian production and consumption by increasing the cultivated area and wheat yield per unit area (Zaki et al., 2012). Wheat production in Egypt using drip irrigation was study by several researchers (Shalby et al., 1997; Selim, 2004; Abd ElRahman, 2009; Eissa et al., 2010; Eissa et al., 2013). In order to get best economic returns from wheat under arid regions, there is an urgent need to identify and adopt effective irrigation and fertilization management strategies. Using drip irrigation improves quality and yield of wheat as well as it increases the water and nutrient use efficiency (Eissa et al., 2010; Abdelraouf et al., 2013; Wang et al., 2013).

Nitrogen $(\mathrm{N})$ is the one of the most limiting factor in wheat production. Hence, the application of nitrogen fertilizers results in higher biomass yields and protein content (Gomaa et al., 2015). Managing $\mathrm{N}$ inputs on wheat production systems is an important issue in order to achieve maximum profitable production and minimum negative environmental impact. Meanwhile, the farmers still believe that increasing nitrogen fertilizer is the only way of obtaining high 
yields of wheat. Indeed, the grain yield of wheat was increased with increasing rates of fertilizer application, which were reported from a series of field experiments (Garabet et al., 1998; Li et al., 2004). However, it is also found that the excessive application of nitrogen cannot increase crop yields further, but considerably increases N leaching (Ju et al., 2009; Hou et al., 2012). Overuse of fertilizer not only increased the high cost of production, but also led to degradation of water and soil quality, especially the groundwater (Zhu et al., 2005; Garnier et al., 2010).

Application of nitrogen $(\mathrm{N})$ fertilizer is very important in winter wheat (Triticum aestivum L.) production. However, unsuitable nitrogen fertilizer often leads to a low nitrogen use efficiency and serious nitrogen loss, bringing a potential risk of pollution to the environment (Zhu et al., 2005; Garnier et al., 2010). There is little information available about the effect of nitrogen fertilization rates on the nutrients uptake, quality, and yield of drip irrigated wheat. The present research aims to study the response of drip irrigated wheat to nitrogen fertilization rates and to assess the optimum fertilization rate.

\section{Materials and Methods \\ Field experiment}

The present investigation was carried out at the Agricultural Experimental Station farm of the Faculty of Agriculture, Assiut University, Egypt, which is located around the point of $27^{\circ} 12 \mathrm{~N}$ latitude and $310^{\circ}$ 09E longitude and at $51 \mathrm{~m}$ altitude. The soil was classified as Typic Torri fluvents according to Soil Taxonomy (Soil Survey Staff, 2014). Selected physical and chemical properties are summarized in Table 1. The experiment included three rates of nitrogen $\left(120,180\right.$, and $\left.240 \mathrm{~kg} \mathrm{ha}^{-1}\right)$. The experimental design was randomized complete block design (RCBD) with three replicates.

Table 1. Some physical and chemical soil properties $(0-30$ and $30-60 \mathrm{~cm})$

\begin{tabular}{|c|c|c|}
\hline Properties & $0-30 \mathrm{~cm}$ & $30-60 \mathrm{~cm}$ \\
\hline Sand $(\%)$ & 24.1 & 24.3 \\
\hline Silt (\%) & 62.4 & 62.5 \\
\hline Clay $(\%)$ & 13.5 & 13.2 \\
\hline Texture & Si. L & Si. L \\
\hline Field capacity (v\%) & 42.7 & 42.5 \\
\hline Witling point (v\%) & 21.1 & 20.1 \\
\hline $\mathrm{CaCO} 3(\%)$ & 5.42 & 5.08 \\
\hline $\mathrm{pH}(1: 2.5$ suspension $)$ & 7.54 & 7.78 \\
\hline $\mathrm{EC}_{\mathrm{e}} \mathrm{dS} \mathrm{m}{ }^{-1}$ & 0.99 & 0.95 \\
\hline Organic matter $\left(\mathrm{g} \mathrm{kg}^{-1}\right)$ & 2.41 & 2.25 \\
\hline Total nitrogen ( $\left.\mathrm{mg} \mathrm{kg}^{-1}\right)$ & 560 & 520 \\
\hline Available nitrogen $\left(\mathrm{mg} \mathrm{kg}^{-1}\right)$ & 67.2 & 62.4 \\
\hline Available Olsen $\mathrm{P}\left(\mathrm{mg} \mathrm{kg}^{-1}\right)$ & 11.78 & 11.32 \\
\hline Available-K $\left(\mathrm{mg} \mathrm{kg}^{-1}\right)$ & 258.1 & 477.4 \\
\hline
\end{tabular}

Each value represents a mean of three replicates

The experimental site was irrigated using a drip irrigation system. The in-line GR dripper laterals were installed $0.7 \mathrm{~m}$ apart. The emitters were spaced $0.30 \mathrm{~m}$ apart with a flow rate of $2.1 \mathrm{~L} \mathrm{~h}^{-1}$. Wheat grains (Triticum aestivum vulgare, cv vinicty 6 ) at rates of $190 \mathrm{~kg} \mathrm{ha}{ }^{-1}$ were sown directly beneath the dripper's line and on the two side of it. The sowing was 
done on December $5^{\text {th }}, 2013$ and December $1^{\text {st }}, 2014$ in the first and second season respectively. All the agriculture practices were applied at the recommendations set by the Ministry of Agriculture and Land Reclamation (Egypt). $238 \mathrm{~kg}$ of super phosphate $\left(15.5 \% \mathrm{P}_{2} \mathrm{O}_{5}\right)$ per hectare was added directly to the soil in one dose before planting. Potassium fertilizer at a rate of $119 \mathrm{~kg}$ potassium sulphate $\left(48 \% \mathrm{~K}_{2} \mathrm{O}\right)$ per hectare was added with the irrigation water in two equal portions. Nitrogen fertilizer levels were applied with the irrigation water in the form of urea $(48 \% \mathrm{~N})$ at five equal doses. Composite plant samples each represent to $1 / 2 \mathrm{~m}^{2}$ were taken from each experimental unit after 70 days of planting (18 samples) and were used to study the uptake of nitrogen, phosphorus, and potassium. These plant samples were cleaned, washed with tap and distilled water, air dried, then dried in oven at $70{ }^{\circ} \mathrm{C}$ until constant weight, ground and stored for chemical analysis. Wheat plants were harvested on May $7^{\text {th }}, 2014$ and May $6^{\text {th }}, 2015$ in first and second seasons respectively and the grain and total yield were recorded.

\section{Irrigation water requirements}

Table 2. Average monthly maximum $\left(T_{\max }\right)$ and minimum $\left(T_{\min }\right)$ temperature, relative humidity (RH), wind speed (WS) and reference evapotranspiration (ET) during 2014 and 2015 growing seasons.

\begin{tabular}{|l|c|c|c|c|c|}
\hline \multicolumn{1}{|c|}{ Month } & $\mathbf{T}_{\mathbf{m a x}}$ & $\mathbf{T}_{\mathbf{m i n}}$ & $\mathbf{R H} \mathbf{( \% )}$ & $\mathbf{E T}_{\mathbf{o}} \mathbf{( m m )}$ & $\left.\mathbf{W S ~}_{\mathbf{( k m ~}} \mathbf{~}^{\mathbf{1}}\right)$ \\
\hline December, 2013 & 20.6 & 7.6 & 40.5 & 2.80 & 2.80 \\
\hline January, 2014 & 22.4 & 6.3 & 55.2 & 2.42 & 3.95 \\
\hline February, 2014 & 23.8 & 7.4 & 49.2 & 3.58 & 6.00 \\
\hline March, 2014 & 27.9 & 12.1 & 42.4 & 4.68 & 5.75 \\
\hline April, 2014 & 32.8 & 15.8 & 34.9 & 5.84 & 5.45 \\
\hline December, 2014 & 23.2 & 8.5 & 48.4 & 3.15 & 7.20 \\
\hline January, 2015 & 20.5 & 5.5 & 44.0 & 3.25 & 8.00 \\
\hline February, 2015 & 22.7 & 7.6 & 38.8 & 4.11 & 8.20 \\
\hline March, 2015 & 27.2 & 12.2 & 34.0 & 5.77 & 9.69 \\
\hline April, 2015 & 29.3 & 14.6 & 25.6 & 6.93 & 9.93 \\
\hline
\end{tabular}


Rainfall was 0 for the two growth season. Data were obtained from Assuit weather station at Central Laboratory for Agricultural Climate

\section{Soil and plant analysis}

Composite soil sample was collected before cultivation from the top $30 \mathrm{~cm}$. Air-dried, crushed, and sieved to pass through a 2-mm. Selected physical and chemical properties of the soil were determined according to Burt (2004). The soil pH was measured in $1: 2.5$ soil to water suspension using a digital $\mathrm{pH}$ meter. The electrical conductivity (EC) was estimated using the salt bridge method (Rhoades, 1982). Available soil nitrogen was extracted by $2 \mathrm{M}$ potassium chloride, and then nitrogen in the extract was determined using micro-kjeldahl method Burt (2004). Available soil phosphorus was extracted by $0.5 \mathrm{M}$ sodium bicarbonate solution at $\mathrm{pH} 8.5$ according to Olsen et al. (1954) and phosphorus was determined by spectrophotometer. Available potassium was extracted by ammonium acetate method and was measured by flame photometry (Jackson, 1973).

Plant samples were digested in $\mathrm{H}_{2} \mathrm{SO}_{4}$ and $\mathrm{H}_{2} \mathrm{O}_{2}$ as described by Parkinson and Allen (1975) then were analyzed for $\mathrm{N}, \mathrm{P}$, and $\mathrm{K}$ as described by Page et al. (1982).

\section{Statistical analysis:}

Data obtained in each season were statistically analyzed. Statistical computer program MSTAT-C, Crop \& Soil Sciences Dept. Michigan State University was used. Mean values were compared for each other using Duncan's test at $P<0.05$. MSTAT (1987) micro computer program.

\section{Results and Discussion \\ Effect of nitrogen rates on the growth of drip irrigated wheat}

The data in Fig. 1 show the wheat plant highest as affected by the different nitrogen fertilization rates. The application of nitrogen to drip irrigated wheat significantly $(P<0.05)$ affected the height of drip irrigated wheat. The height increase due to the rate of nitrogen $\left(240 \mathrm{~kg} \mathrm{ha}^{-1}\right)$ was 16 and $7 \%$ increase in the plant height in the first and second season, respectively, compared to the low treatment $\left(120 \mathrm{~kg} \mathrm{ha}^{-1}\right)$. Fig 2 and 3 illustrated the effect of nitrogen fertilization on the fresh and dry wheat. The highest significant values of fresh and dry weights were obtained when wheat amended with $240 \mathrm{~kg} \mathrm{ha}^{-1}$. The application of nitrogen at a rate of 240 $\mathrm{kg} \mathrm{N}$ per hectare increased the fresh weights by 40 and $39 \%$ in the first and second season, respectively, compared to the low treatment (120 $\mathrm{kg} \mathrm{N} \mathrm{ha}{ }^{-1}$ ). The application of nitrogen at a rate of $240 \mathrm{~kg} \mathrm{~N}$ per hectare increased the dry weights by 40 and $34 \%$ in the first and second seasons, respectively, compared to the low treatment $\left(120 \mathrm{~kg} \mathrm{~N}^{-1}\right)$. The current study indicates that increasing nitrogen rates increased the growth of drip irrigated wheat. Nitrogen plays a vital role in all living tissues of the plants and is a constituent of many fundamental cell components such as nucleic acids, amino acids, enzymes, and photosynthetic pigments (Bungard et al., 1999). Hussain et al. (2006) studied the response of wheat to five rates of nitrogen i.e., 0,50 , 100,150 , and $200 \mathrm{~kg} \mathrm{ha}^{-1}$ and they reported that increasing $\mathrm{N}$ rates increased the dry matter production of wheat. Ryan et al. (1991), Davidson and Campbell (1983), and Pala et al. 
(1996) proposed that this increase may be due to the increase leaf of area index, green plant area, and an increase in the period for which the crop remained green which resulted in increased capture efficiency of radiation energy and consequently more dry matter production.

Fig. 1: Plant height of 70 days-old wheat $(\mathrm{cm})$ as affected by nitrogen fertilization rates

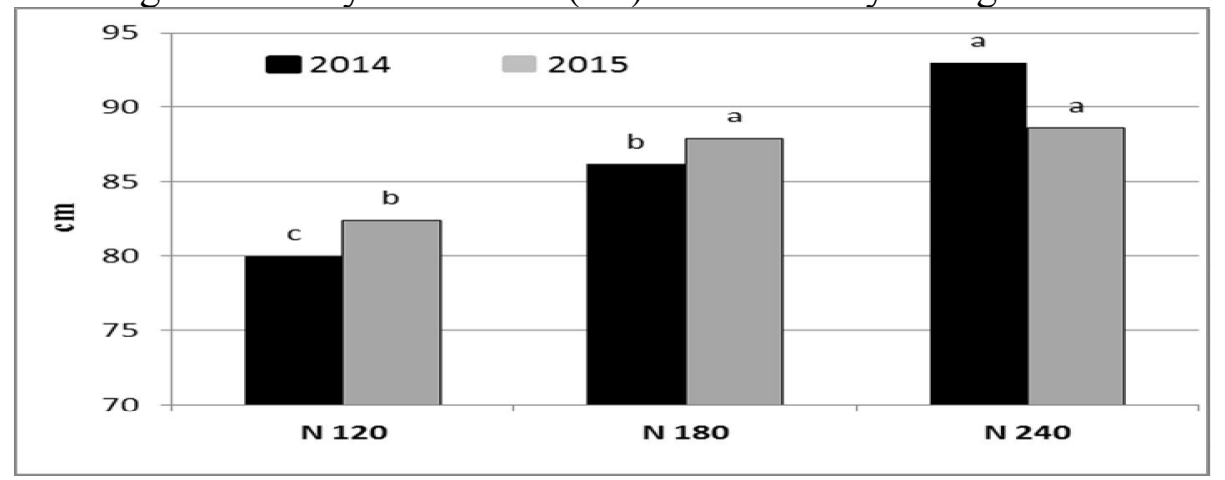

Means denoted by the same letter indicate no significant difference according to Duncan's test at $P<0.05$.

Fig. 2: Fresh weight of 70 days-old wheat $\left(\mathrm{kg} \mathrm{ha}^{-1}\right)$ as affected by nitrogen fertilization rates

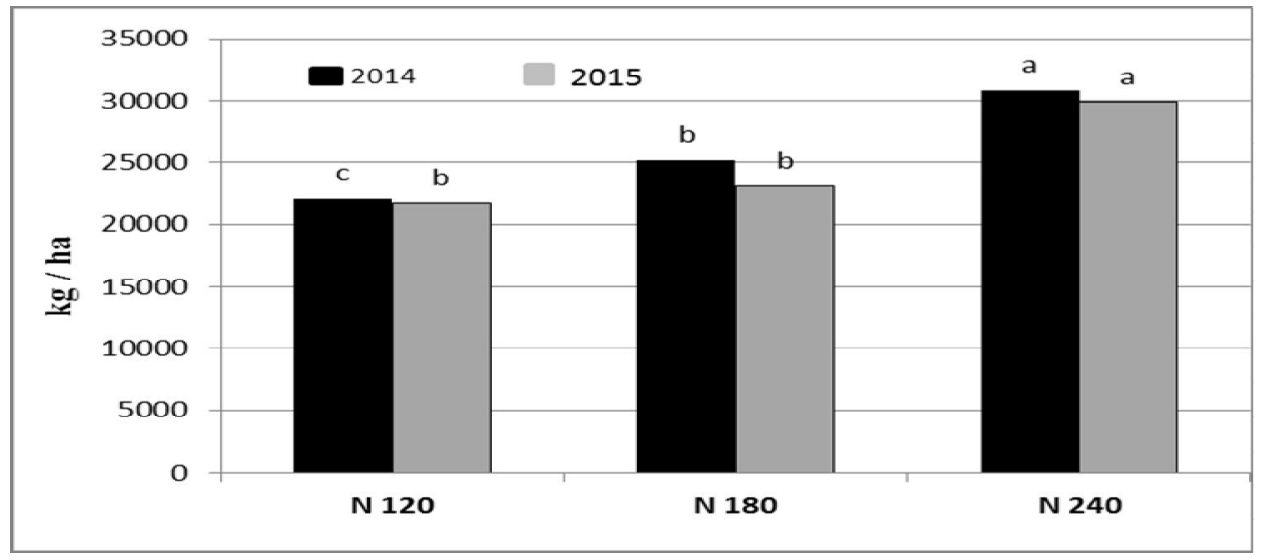

Means denoted by the same letter indicate no significant difference according to Duncan's test at $P<0.05$

Fig. 3: Dry weight of 70 days-old wheat $\left(\mathrm{kg} \mathrm{ha}^{-1}\right)$ as affected by nitrogen fertilization rates

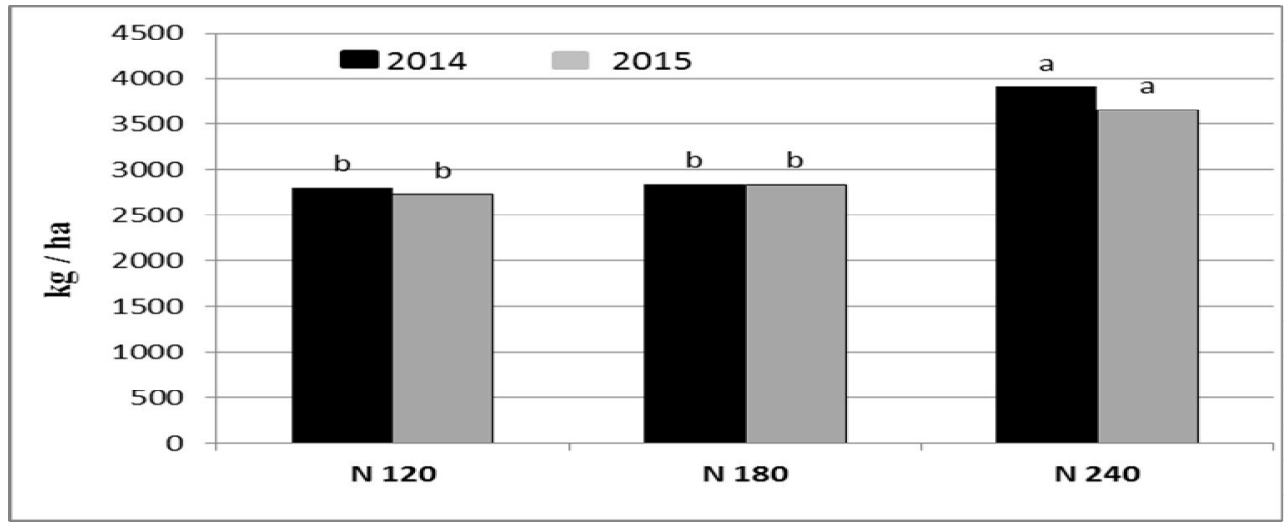

Means denoted by the same letter indicate no significant difference according to Duncan's test at $P<0.05$. 
Effect of nitrogen rates on $\mathrm{N}$, $\mathrm{P}$, and $K$ concentrations and uptake by drip irrigated wheat

The data illustrated in Table 3 show the nitrogen $(\mathrm{N})$, phosphorus $(\mathrm{P})$, and potassium $(\mathrm{K})$ concentrations in the shoots of 70 days-old wheat as affected by nitrogen fertilization rates. The application of nitrogen to drip irrigated wheat significantly $(P<0.05)$ affected the concentrations of $\mathrm{N}, \mathrm{P}$, and $\mathrm{K}$. The highest significant values of $\mathrm{N}, \mathrm{P}$, and $\mathrm{K}$ concentrations were obtained when wheat amended with $240 \mathrm{~kg} \mathrm{ha}^{-1}$. The application of nitrogen at a rate of 240 $\mathrm{kg} \mathrm{N}$ per hectare increased the concentrations of $\mathrm{N}$ by 16.4 and $6.4 \%$ in the first and second seasons, respectively, compared to the low treatment $\left(120 \mathrm{~kg} \mathrm{~N} \mathrm{ha}{ }^{-1}\right)$. The application of nitrogen at a rate of $240 \mathrm{~kg} \mathrm{~N}$ per hectare increased the concentrations of $\mathrm{P}$ by 25.4 and $31.4 \%$ in the first and second seasons, respectively, compared to the low treatment (120 $\mathrm{kg} \mathrm{N} \mathrm{ha}{ }^{-1}$ ). The application of nitrogen at a rate of $240 \mathrm{~kg} \mathrm{~N}$ per hectare increased the concentrations of $\mathrm{K}$ by 21.1 and $5.7 \%$ in the first and second seasons, respectively, compared to the low treatment $\left(120 \mathrm{~kg} \mathrm{~N} \mathrm{ha}^{-1}\right)$. In general, the concentrations of $\mathrm{N}, \mathrm{P}$, and $\mathrm{K}$ in the shoots of drip irrigated wheat responded to all the studied nitrogen rates and the highest significant values were recorded when $\mathrm{N}$ was applied at a rate of $240 \mathrm{~kg} \mathrm{~N}$ per hectare.

The data illustrated in Table 3 show the nitrogen $\mathrm{N}, \mathrm{P}$, and $\mathrm{K}$ uptake by the 70 days-old wheat as affected by the nitrogen fertilization rates. The application of nitrogen to drip irrigated wheat significantly $(P<0.05)$ affected the uptake of $\mathrm{N}, \mathrm{P}$, and $\mathrm{K}$. The highest significant uptake of $\mathrm{N}$, $\mathrm{P}$, and $\mathrm{K}$ were obtained when wheat amended with $240 \mathrm{~kg} \mathrm{ha}^{-1}$. The application of nitrogen at a rate of 240 $\mathrm{kg} \mathrm{N}$ per hectare increased the uptake of $\mathrm{N}$ by $61 \%$ in the first season compared to the low treatment $(120 \mathrm{~kg} \mathrm{~N}$ $\mathrm{ha}^{-1}$ ). The application of nitrogen at a rate of $240 \mathrm{~kg} \mathrm{~N}$ per hectare increased the uptake of P by 75 and $76 \%$ in the first and second season, respectively, compared to the low treatment (120 $\mathrm{kg} \mathrm{N} \mathrm{ha}^{-1}$ ). The application of nitrogen at a rate of $240 \mathrm{~kg} \mathrm{~N}$ per hectare increased the uptake of $\mathrm{K}$ by 57 and $42 \%$ in the first and second season, respectively, compared to the low $\mathrm{N}$ treatment $\left(120 \mathrm{~kg} \mathrm{~N} \mathrm{ha}^{-1}\right)$.

Table 3. $\mathrm{N}, \mathrm{P}$, and $\mathrm{K}$ concentrations $\left(\mathrm{g} \mathrm{kg}^{-1}\right)$ and uptake $\left(\mathrm{kg} \mathrm{ha}^{-1}\right)$ by 70 days-old wheat as affected by nitrogen fertilization rates

\begin{tabular}{|c|c|c|c|c|c|c|c|c|c|c|c|c|}
\hline & \multicolumn{6}{|c|}{2014} & \multicolumn{6}{|c|}{2015} \\
\hline & \multicolumn{2}{|c|}{$\mathrm{N}$} & \multicolumn{2}{|c|}{$P$} & \multicolumn{2}{|c|}{ K } & \multicolumn{2}{|c|}{$\mathrm{N}$} & \multicolumn{2}{|c|}{$\mathrm{P}$} & \multicolumn{2}{|c|}{$\mathrm{K}$} \\
\hline & conc. & $\begin{array}{l}\text { Up- } \\
\text { take }\end{array}$ & conc. & uptake & conc. & uptake & conc. & $\begin{array}{c}\text { up- } \\
\text { take }\end{array}$ & conc. & uptake & conc. & uptake \\
\hline $\begin{array}{c}\mathrm{N}_{12} \\
0\end{array}$ & $\begin{array}{c}36.220 \\
\mathrm{~b}\end{array}$ & $101 \mathrm{c}$ & $5.978 \mathrm{c}$ & $16.74 \mathrm{c}$ & $30.268 \mathrm{c}$ & $103.0 \mathrm{c}$ & $\begin{array}{c}37.80 \\
\mathrm{~b}\end{array}$ & $117 \mathrm{a}$ & $7.21 \mathrm{c}$ & $17.09 \mathrm{c}$ & $34.70 \mathrm{c}$ & $94.54 \mathrm{c}$ \\
\hline $\begin{array}{c}\mathrm{N}_{18} \\
0\end{array}$ & $40.620 \mathrm{a}$ & $115 b$ & $\begin{array}{c}6.850 \\
\mathrm{~b}\end{array}$ & $\begin{array}{c}19.41 \\
\mathrm{~b}\end{array}$ & $\begin{array}{c}35.667 \\
\mathrm{~b}\end{array}$ & $\begin{array}{c}108.5 \\
\mathrm{~b}\end{array}$ & $\begin{array}{c}38.30 \\
\mathrm{~b}\end{array}$ & $113 a$ & $\begin{array}{c}7.78 \\
\mathrm{~b}\end{array}$ & $\begin{array}{c}22.05 \\
\mathrm{~b}\end{array}$ & $38.59 \mathrm{a}$ & $\begin{array}{c}109.33 \\
\mathrm{~b}\end{array}$ \\
\hline $\begin{array}{c}\mathrm{N}_{24} \\
0\end{array}$ & $42.173 \mathrm{a}$ & $165 a$ & $7.500 \mathrm{a}$ & $29.30 \mathrm{a}$ & $36.667 \mathrm{a}$ & $162.8 \mathrm{a}$ & $40.22 \mathrm{a}$ & $122 \mathrm{a}$ & $8.24 \mathrm{a}$ & $30.12 \mathrm{a}$ & $\begin{array}{c}36.68 \\
\text { b }\end{array}$ & 134.0 \\
\hline
\end{tabular}


Based on the data in Table 3, the concentrations and uptake of $\mathrm{N}$, $\mathrm{P}$, and $\mathrm{K}$ by drip irrigated wheat responded to all the studied nitrogen rates and the highest significant values were recorded when $\mathrm{N}$ was applied at a rate of $240 \mathrm{~kg} \mathrm{~N}$ per hectare. Addition of $\mathrm{N}$ could stimulate development of plant roots, contributing to increased nutrients uptake (Zhang et al., 2004). Campillo et al. (2010) studied the response of wheat to five rates of nitrogen i.e., 0,150 , 200,250 , and $300 \mathrm{~kg} \mathrm{ha}^{-1}$ and they reported that increasing $\mathrm{N}$ rates increased the $\mathrm{N}$ concentrations in wheat tissues. Similar results were reported by Hussain et al. (2006). The application of nitrogen improves the root growth and this will increase the ability of roots to explore more soil and increases the uptake of nutrients. Zhang et al. (2004) reported that added $\mathrm{N}$ increased the growth of roots and produced a mass of fine roots. Moreover, the application of nitrogen may be increase the availability of nutrients in soil. Ouyang et al. (1999) stated that application of nitrogen fertilizer not only increased soluble $\mathrm{P}$ concentrations in the band area, but increased $\mathrm{P}$ diffusion from the fertilizer zone to the surrounding soil as well. In the current study, drip irrigated wheat was fertilized by different rates of nitrogen in the form of urea. Once incorporated in the soil, urea reacts through hydrolysis to form $\mathrm{NH}^{+4}$ ions (Mitchell et al., 2000). $\mathrm{NH}^{+4}$ ions enhancing rhizosphere acidification and may increase $\mathrm{P}$ availability and plant uptake (Zhang et al., 2004). Interactions between $\mathrm{N}$ and $\mathrm{K}$ in crop fertilization have been described by several stu- dies. Increasing rates of nitrogen increased the availability and uptake of $\mathrm{K}$ where $\mathrm{NH}^{+4}$ compete with the exchangeable K (Rowe et al., 2008; Zhang et al. 2010; Bar-Tal, 2011).

Effect of nitrogen rates on spike number, grain number, and grain weight of drip irrigated wheat

The data in Table 4 show the number of spike (NS) per $\mathrm{m}^{2}$, number of grains (NG) per spike, and grain weight (GW) per spike of wheat as affected by the different rates of nitrogen. The number of spike per $\mathrm{m}^{2}$ and number of grain per spike significantly $(P<0.05)$ affected by the application of nitrogen in both the two season. The highest significant NP and NG values were obtained when wheat amended with $240 \mathrm{~kg} \mathrm{ha}^{-1}$. The application of nitrogen at a rate of $240 \mathrm{~kg} \mathrm{~N}$ per hectare increased the NP by 17 and $5 \%$ in the first and second season, respectively, compared to the low treatment $(120 \mathrm{~kg} \mathrm{~N}$ $\mathrm{ha}^{-1}$ ). The application of nitrogen at a rate of $240 \mathrm{~kg} \mathrm{~N}$ per hectare increased the NG by 15.7 and $14 \% \mathrm{n}$ the first and second season, respectively, compared to the low treatment $(120$ $\mathrm{kg} \mathrm{N} \mathrm{ha}{ }^{-1}$ ). The application of nitrogen at a rate of $240 \mathrm{~kg} \mathrm{~N}$ per hectare increased the GW by 17 and $3.0 \%$ in the first and second season, respectively, compared to the low treatment $\left(120 \mathrm{~kg} \mathrm{~N} \mathrm{ha}^{-1}\right)$. In general, the number of spike per $\mathrm{m}^{2}$, number of grains per spike, and grain weight per spike of wheat were affected significantly by the different rates of nitrogen and the highest significant values were recorded when $\mathrm{N}$ was applied at a rate of $240 \mathrm{~kg} \mathrm{~N}$ per hectare. Mandic et al. (2015) studied the effect of three rates of $\mathrm{N}(0,75$, and $150 \mathrm{~kg} \mathrm{~N}$ 
$\mathrm{ha}^{-1}$ ) on wheat growth and they found that increasing $\mathrm{N}$ rates increased number of spike per $\mathrm{m}^{2}$, number of grains per spike, and grain weight

Table 4. Number of spike (NS) per $\mathrm{m}^{2}$, number of grains (NG) per spike, and grain weight $(\mathrm{GW})$ per spike in gram

\begin{tabular}{|l|c|c|c|c|c|c|}
\hline & \multicolumn{3}{|c|}{2014} & \multicolumn{3}{c|}{2015} \\
\hline & NS & NG & GW & NS & NG & GW \\
\hline $\mathrm{N}_{120}$ & $496.0 \mathrm{c}$ & $89.3 \mathrm{c}$ & $4.7 \mathrm{a}$ & $469.3 \mathrm{~b}$ & $92 \mathrm{c}$ & $4.91 \mathrm{a}$ \\
\hline $\mathrm{N}_{180}$ & $626.0 \mathrm{a}$ & $97.5 \mathrm{~b}$ & $4.6 \mathrm{a}$ & $452.0 \mathrm{~b}$ & $100 \mathrm{a}$ & $4.67 \mathrm{a}$ \\
\hline $\mathrm{N}_{240}$ & $580.3 \mathrm{~b}$ & $103.0 \mathrm{a}$ & $5.5 \mathrm{a}$ & $494.3 \mathrm{a}$ & $105 \mathrm{a}$ & $5.06 \mathrm{a}$ \\
\hline
\end{tabular}

Means denoted by the same letter indicate no significant difference according to Duncan's test at $P<0.05$.

Effect of nitrogen rates on yield and yield components of drip irrigated wheat

The data in Table 5 show the grain (GY), straw (SY), and biological yield (BY) of wheat as affected by the different rates of nitrogen. The grain yield ranged from 5083 to 8884 $\mathrm{kg} \mathrm{ha}^{-1}$ while the straw yield ranged from 20315 to $25536 \mathrm{~kg} \mathrm{ha}^{-1}$. Wheat biological yield ranged from 26933 to $31750 \mathrm{~kg} \mathrm{ha}^{-1}$. The application of nitrogen to drip irrigated wheat significantly $(P<0.05)$ affected on yield and yield components of wheat in both the two seasons. The highest significant grain, straw, and biological yield was obtained when wheat was amended with $240 \mathrm{~kg} \mathrm{ha}^{-1}$. The application of nitrogen at a rate of 240 $\mathrm{kg} \mathrm{N}$ per hectare increased the wheat grain yield by 34 and $22 \%$ in the first
(GW) per spike. Similar results were reported by Hussain et al. (2006) and Asif et al. (2012). and second seasons, respectively, compared to the low treatment (120 $\mathrm{kg} \mathrm{N} \mathrm{ha}{ }^{-1}$ ). The application of nitrogen at a rate of $240 \mathrm{~kg} \mathrm{~N}$ per hectare increased the wheat straw yield by 10.5 and $16.4 \% \mathrm{n}$ the first and second season, respectively, compared to the low treatment $\left(120 \mathrm{~kg} \mathrm{~N}^{-1}\right)$. The application of nitrogen at a rate of $240 \mathrm{~kg} \mathrm{~N}$ per hectare increased the wheat biological yield by 16.4 and $17.5 \%$ in the first and second seasons, respectively, compared to the low treatment $\left(120 \mathrm{~kg} \mathrm{~N} \mathrm{ha}^{-1}\right)$. In general, yield and yield components of drip irrigated wheat responded to all the studied nitrogen rates and the highest significant grain, straw, and biological yield were recorded when $\mathrm{N}$ was applied at a rate of $240 \mathrm{~kg} \mathrm{~N}$.

Table 5. Grain (GY), straw (SY), and biological yield (BY) of wheat $\left(\mathrm{Kg} \mathrm{ha}^{-1}\right)$ as affected by nitrogen fertilization rates

\begin{tabular}{|l|c|c|c|c|c|c|}
\hline & \multicolumn{3}{|c|}{$\mathbf{2 0 1 4}$} & \multicolumn{2}{c|}{$\mathbf{2 0 1 5}$} \\
\hline & GY & SY & BY & GY & SY & BY \\
\hline $\mathrm{N}_{120}$ & $6618^{\mathrm{c}}$ & $20315^{\mathrm{b}}$ & $26933^{\mathrm{b}}$ & $5083^{\mathrm{c}}$ & $21935^{\mathrm{c}}$ & $27019^{\mathrm{c}}$ \\
\hline $\mathrm{N}_{180}$ & $7027^{\mathrm{b}}$ & $20810^{\mathrm{b}}$ & $27837^{\mathrm{b}}$ & $5546^{\mathrm{b}}$ & $23931^{\mathrm{b}}$ & $29477^{\mathrm{b}}$ \\
\hline $\mathrm{N}_{240}$ & $8884^{\mathrm{a}}$ & $22462^{\mathrm{a}}$ & $31346^{\mathrm{a}}$ & $6214^{\mathrm{a}}$ & $25536^{\mathrm{a}}$ & $31750^{\mathrm{a}}$ \\
\hline
\end{tabular}

Means denoted by the same letter indicate no significant difference according to Duncan's test at $P<0.05$.

High yields are the result of environmental, technological, manage- ment, capital, and input conditions. High wheat yields require increases 
in $\mathrm{N}$ application (Semenov et al., 2007; Campillo et al., 2010). Many studies have shown that increasing the fertilizer $\mathrm{N}$ rate properly can increase the grain, straw, and biological yield of wheat (Subedi et al., 2007, Asif et al., 2012; Mandic et al. 2015). $\mathrm{Yu}$ and Zhenwen (2008) studied the response of wheat irrigated by traditional surface irrigation to three levels of $\mathrm{N}$ i.e., 0,168 , and $240 \mathrm{~kg} \mathrm{~N} \mathrm{ha}^{-1}$ and they found that the application of $\mathrm{N}$ fertilizer increased the grain yield and protein content of the grain. Similar results were reported by Han et al.(1998) and Yue et al. (1998).

Effect of nitrogen rates on water use efficiency of drip irrigated wheat
The data in Fig. 4 and 5 show the water use efficiency and irrigation water use efficiency of wheat as affected by the different rates of nitrogen. The application of nitrogen to drip irrigated wheat significantly $(P<0.05)$ affected on water use efficiency and irrigation water use efficiency in both the two seasons. Increasing rate of nitrogen to $240 \mathrm{~kg} \mathrm{~N}$ per hectare increased the WUE by 34 and $22 \%$ in the first and second seasons, respectively, compared to the lowest rate $\left(120 \mathrm{~kg} \mathrm{~N} \mathrm{ha}^{-1}\right)$. The application of $240 \mathrm{~kg} \mathrm{~N} \mathrm{ha}^{-1}$ increased the IWUE by 34 and $21 \%$ compared to the lowest rate.

Fig. 4: Water use efficiency (WUE) of wheat ( $\mathrm{kg}$ grain yield $\mathrm{mm}^{-1}$ of water) as affected by nitrogen fertilization rates

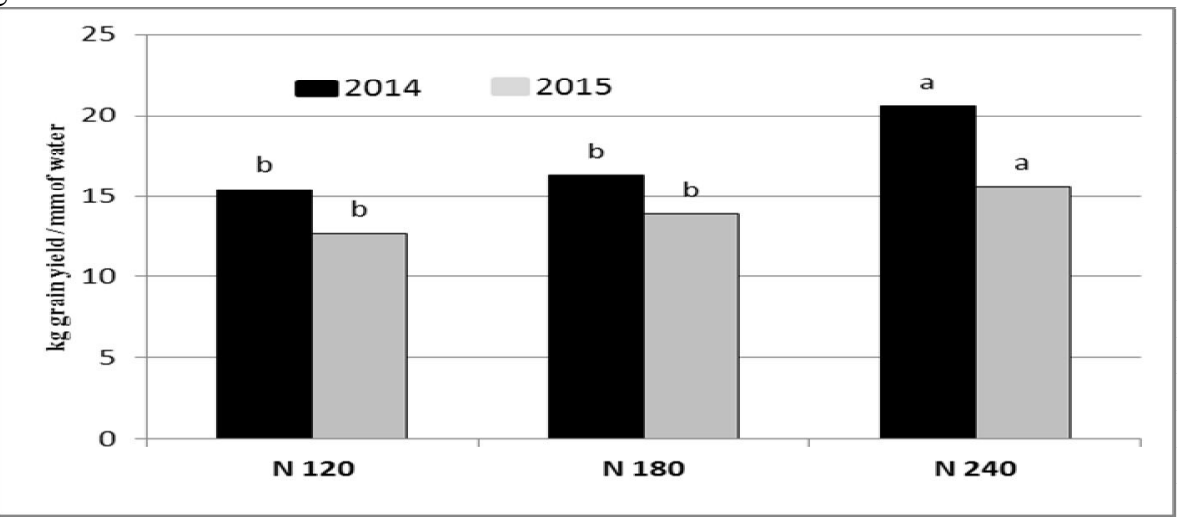

Means denoted by the same letter indicate no significant difference according to Duncan's test at $P<0.05$.

Fig. 5: Irrigation water use efficiency (IWUE) of wheat ( $\mathrm{kg}$ grain yield $\mathrm{mm}^{-1}$ of water) as affected by nitrogen fertilization rates

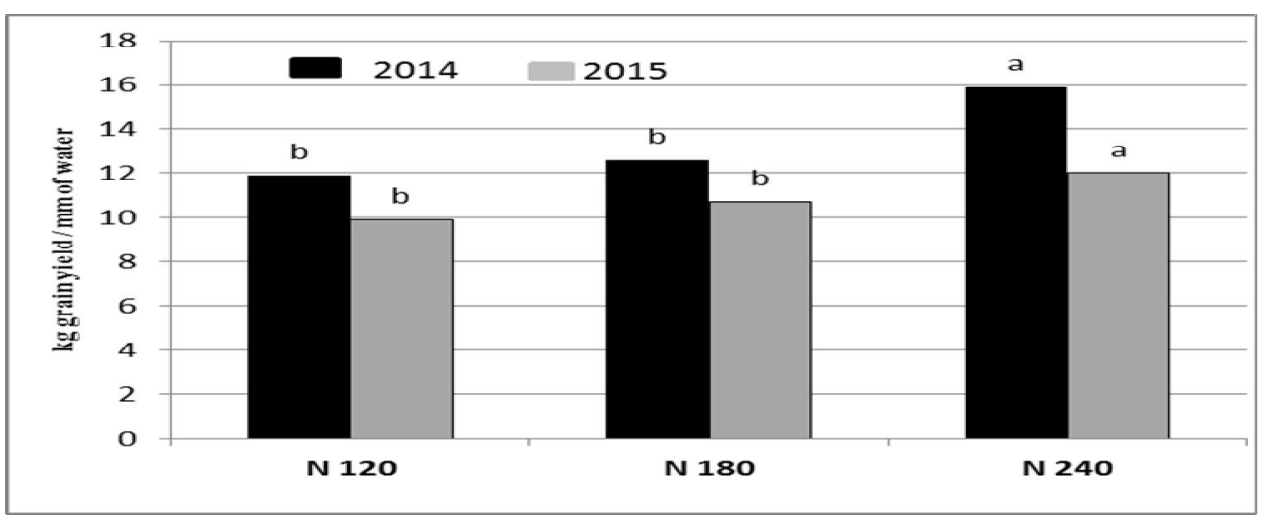


Means denoted by the same letter indicate no significant difference according to Duncan's test at $P<0.05$.

In the current study, drip irrigated wheat used water more efficiently under the high rate of nitrogen. Investigations have shown that WUE of wheat increased with increasing nitrogen rates (Hussain, AlJaloud, 1995; Wang et al., 2012; Shirazi et al., 2014). Increasing water use efficiency requires increasing photosynthetic capacity; therefore, more nitrogen will required (Martin et al., 2010). Nitrogen is a major limiting factor of plant growth and development. Nitrogen is an integral part of DNA, RNA, chlorophyll and proteins, plays an important role in cell metabolism, affects photosynthetic capacity of leaves by increasing stromal and thylakoid proteins in leaves (Marschner, 1995; Bungard et al., 1997).

It may be concluded that, nitrogen fertilization enhanced the growth and yield of drip irrigated wheat. Moreover, N application improved the uptake of nutrients and enhanced water use efficiency. Based on the obtained results, $240 \mathrm{~kg}$ per hectare is the optimum nitrogen level for drip irrigated wheat.

\section{References}

Abd El-Rahman, G. 2009. Water use efficiency of wheat under drip irrigation systems at AlMaghara Area, North Sinai, Egypt. American-Eurasian J. Agric. \& Environ. Sci., 5 (5): 664-670.

Abdelraouf, R.E., S.F. El Habbasha, M.H. Taha and K.M. Refaie. 2013. Effect of irrigation water requirements and fertigation levels on growth, yield and water use efficiency in wheat. MiddleEast Journal of Scientific Research 16 (4): 441-450

Allen, G. R., L. S. Pereira, D. Raesand and M. Smith. 1998. Crop evapotranspiration guidelines for competing crop water requirements. FAO. Irrigation and drainage paper 56. Rome, Italy, p. 300 .

Al-Omran, A. M., A. S. Sheta., A. M. Falatah, and A. R. Al-Harbi. 2005. Effect of drip irrigation on squash (Cucurbi tapepo) yield and water-use efficiency in sandy calcareous soils amended with clay deposits. Agricultural Water Management 73 (1): $43-$ 55.

Asif, M., M. Maqsood, A. Ali, S.W. Hassan, A. Hussain and S. Ahmad. 2012. Growth yield components and harvest index of wheat (Triticum aestivum L.) affected by different irrigation regimes and nitrogen management strategy. Science International (Lahore) 24:215-218.

Aujla, M. S., H. S. Thind and G. S. Buttar. 2007. Fruit yield and water use efficiency of eggplant (Solanumme longema L.) as influenced by different quantities of nitrogen and water applied through drip and furrow irrigation. Scientia Horticulturae 112 (2): 142-148.

Bar-Tal A. 2011. The Effects of Nitrogen Form on Interactions with Potassium. Nitrogen and Potassium Interactions. Switzerland, International Potash Institute. Pp.9 http://www.ipipotash. 
org/en/eifc/2011/29/3/english

(Accessed 27/1/2014)

Bar-Yosef, B. 1999. Advances in fertigation. Advances in Agronomy 65:1-79.

Bungard, R. A., A. McNeil and J. D. Morton. 1997. Effect of nitrogen on the photosynthetic apparatus of clematis suitable grown at several irradiances. Australian Journal of Plant Physiology 24: 205-214.

Bungard, R.A., A. Wingler, J.D. Morton and M. Andrews. 1999. Ammonium can stimulate nitrate and nitrite reductase in the absence of nitrate in Clematisitalba. Plant Cell and Environment, 22:859-866. doi:10.1046/j.1365-3040.1999. 00456.x.

Burt, R. 2004. Soil survey laboratory methods manual. Soil Survey Investigations Report No. 42, Version 4.0, Natural Resources Conservation Service, United States Department of Agriculture.

Campillo, R., C. Jobet and P. Undurraga. 2010. Effects of nitrogen on productivity, grain quality, and optimal nitrogen rates in winter wheat cv. Kumpa-inia in Andisols of southern Chile. Chilean J. Agric. Res. . 70 (1): 122131

Davidson, H. R. and C. A. Campbell. 1983. The effect of temperature, moisture and nitrogen on the rate of deveiopment of spring wheat as measured by degree days. Can. J. Plant Sci. 63: 833846.

Eissa, M. A., M. Nafady, H. Ragheb and K.Attia. 2010. Management of phosphorus fertigation for drip irrigated wheat under sandy calcareous soils. World Journal of Agricultural Sciences 6(5): 510-516.

Eissa, M. A., M. Nafady, H. Ragheb and K.Attia. 2013. Effect of soil moisture and forms of phosphorus fertilizers on corn production under sandy calcareous Soil. World Applied Sciences Journal 26 (4): 540-547.

FAOSTAT, 2014. Food and Agriculture Organization of the United Nations http://www.fao.org/ giews/english/cpfs/index.htm\#2 014

Fucang Z, K. Shaozhong, Z. Jianhua , Z. Renduo and F. Li. 2004. Nitrogen Fertilization on Uptake of Soil Inorganic Phosphorus Fractions in the Wheat Root Zone. Soil Sci. Soc. Am. J. 68:1890-1895.

Garabet, S., J. Ryan and M. Wood. 1998. Nitrogen and water effects on wheat yield in a Mediterranean type climate. II. Fertilizer-use efficiency with label led nitrogen. Field Crops Res. 58: 213-221.

Garnier, M., F. Recanatesi, M.N. Ripa and A. Leone. 2010. Agricultural nitrate monitoring in a lake basin in central Italy: A further step ahead towards an integrated nutrient management aimed at controlling water pollution. Environ. Monitor. Assess. 170: 273-286.

Gomaa, M.A., F.I. Radwan, I.F. Rehab and W.S. Mabrouk. 2015. Response of Bread Wheat to Organic and Nitrogen Fertiliza- 
tion. Middle East J. Agric. Res., 4(4): 712-716.

Han Y.L., X.L. Jie, J.F. Tan, T.C. Guo, Y.J. Zhu, C.Y. Wang, G.J. Xia, and Z. Liu. 1998. Studies on absorption distribution and translocation of $\mathrm{N}, \mathrm{P}$ and $\mathrm{K}$ of super-high-yielding winter wheat. Acta Agronomica Sinica, 24(6): 908-915.

Hou, P., Q. Gao, R. Xie, S Li, Q. Meng, E.A. Kirkby, V. Römheld, T. Müller, F. Zhang and Z. Cui. 2012. Grain yields in relation to $n$ requirement: Optimizing nitrogen management for spring maize grown in china. Field Crops Res., 129:1-6.

Hussain, G. and A.A. Al-Jaloud. 1995. Effect of irrigation and nitrogen on water use efficiency of wheat in Saudi Arabia Agric. Water Manage., 27:143-153.

Hussain, I., M.A. Khan and E.A. Khan. 2006. Bread wheat varieties as influenced by different nitrogen levels. Journal of Zhejiang University SCIENCE B 2006 7(1):70-78

Jackson, M.L., 1973. Soil chemical analysis. Prentice-Hall, Inc. Englewood Cliffs, N.J. New Delhi, India.

Ju, X.T., G.X. Xing, X.P. Chen, S.L. Zhang, L.J. Zhang, X.J. Liu, Z.L. Cui B. Yin, P. Christie and Z.L. Zhu.2009. Reducing environmental risk by improving $n$ management in intensive Chinese agricultural systems. Proc. Natl. Acad. Sci. USA, 106: 3041-3046.

Li, Z.Z., W.D.Li and W.L. Li. 2004. Dry-period irrigation and fertilizer application affect water use and yield of spring wheat in semi-arid regions. Agric. Water Manag. 65:133-143.

Liang, X., Y. Gao, X. Zhang, Y. Tian and Z. Zhang. 2014. Effect of optimal daily fertigation on migration of water and salt in soil, root growth and fruit yield of cucumber (Cucumissativus L.) in solar-greenhouse. PLOS ONE 9(1): e86975. doi:10.1371/ journal.pone. 0086975

Mandic, V., KVesna, T.Zorica, B. Zorica, S. Aleksandar, M. Dragana, R. Muslic, and M. Gogic. 2015. Nitrogen fertilizer influence on wheat yield and use efficiency under different environmental conditions. Chilean Journal of Agricultural Research 75(1) January -March 2015.

Marschner, H. 1995. Mineral Nutrition of Higher Plants. London: Academic Press.

Martin K.C, D. Bruhn, C.E. Lovelock, I.C Feller, J. Evans and M.C. Ball 2010. Nitrogen fertilization enhances water use efficiency in a saline environment. Plant, Cell \& Environment 33:344-357.

Mathieu, N., G. Y. Wang, and R. Goldy. 2007. Withholding of drip irrigation between transplanting and flowering increases the yield of field-grown tomato under plastic mulch. Agriculture Water Management 87 (3): 285-291.

Melgar, J. C., W.A. Schumann and J.P. Syvertsen. 2010. Fertigation frequency affects growth and water and nitrogen use efficiencies of Swingle Citrumelo Ci- 
trus Root stock Seedlings. Hortscience 45(8):1255-1259.

Mitchell, L., C. Grant and G. Racz. 2000. Effect of nitrogen application on concentration of cadmium and nutrient ions in soil solution and in durum wheat. Can. J. Soil Sci. 80, 107-115.

MSTAT 1987. A microcomputer program for the design, management and analysis of agronomic research experiments. Michigan State University

Olsen, S.R., C.V. Cole, F.S. Watanabe and L.A. Dean. 1954. Estimation of available phosphorus in soils by extraction with sodium bicarbonate. United States Department of Agriculture Circular 939, Washington, DC, 19 p.

Ouyang, D.S., A.F.M.Kenzie and M.X. Fan. 1999. Availability of banded triple superphosphate with urea and phosphorus use efficiency by corn Nutrient Cycling in Agroeco systems 53: 237-247.

Page, A.L. (Ed). 1982. Methods of Soil analysis. Part 2: Chemical and microbiological properties ,(2nd Ed). Am. Soc. At Agron.Inc. Soil Sci. Soc. Of Am., Madison, Wisconsin, USA.

Pala, M., A.Matar and A Mazid. 1996. Assessment of the effect of environmental factors on the response of wheat to fertilizer in on-farm trials in A Mediterranean type environment. Exp. Agric. 32: 339-349.

Parkinson, J.A. and S.E. Allen (1975). A Wet Oxidation Procedure Suitable for the Determina- tion of Nitrogen and Mineral Nutrients in Biological Materials. Communications in Soil Science and Plant Analysis, 6: 1-11.

Rhoades, J.D. 1982. Soluble salts. P.167-180 In A.L. Page, R.H. Miller and D.R. Keeney. Methods of soil analysis, part 2 . Chemical and microbiological properties 2nd edition. Soil Sci. Soc. Am. Inc., Madison, WI, USA

Rowe, E.C., S.M. Smart, V.H. Kennedy, B.A. Emmett and C.D. Evans. 2008. Nitrogen deposition increases the acquisition of phosphorus and potassium by heather Calluna vulgaris. Environmental Pollution, 155:201-207.

Ryan, J.M., M. Abdel Monem, M. Mergoumand M. El Gharous. 1991. Comparative triticale and barley responses to nitrogen under varying rain fall locations in Morocco's dry land zone. Rachis 10 (2): 3-7.

Schumann, A. W., J. P. Syvertsen, and K. T. Morgan. 2009. Implementing advanced citrus production systems in Florida-Early results. Proceeding of Florida State Hort science Society 122:108-113.

Selim, A. M. 2004. Response of wheat to different N- applications and irrigation systems under arid conditions International Conf. on Water Resources \& Arid Environment (2004).

Semenov, M.A., P.D. Jamieson, and P. Martre. 2007. De convoluting nitrogen use efficiency in 
wheat: A simulation study. Eur. J. Agron. 26:283-294.

Shalby, E.M., F.H. Abdallah, A.Y.Alam and E.A.Aly. 1997. Production of wheat by using new modern systems of irrigation in new reclaimed soils. Proceeding of $1^{\text {st }}$ Scientific Conference of Agricultural Science Faculty of Agric. Assiut Univ.,December 13-14, 1997 Vol 1, 1-13

Shirazi, S.M, Y. Zulkifli, N. H. Zardari, and Z. Ismail, 2014. Effect of Irrigation Regimes and Nitrogen Levels on the Growth and Yield of Wheat, Advances in Agriculture, vol. 2014, Article ID 250874, 2014. doi: $10.1155 / 2014 / 250874$

Soil Survey Staff, 2014. Keys to Soil Taxonomy, 11th ed. USDANatural Resources Conservation Services, Washington, DC.

Subedi, K.D., B.L. Ma and A.G. Xue. 2007. Planting date and nitrogen effects on grain yield and protein content of spring wheat. Crop Science 47:36-44.

Wang, J., S Gong, D. Xu, Y. Yu, and Y. Zhao. 2013. Impact of drip and level-basin irrigation on growth and yield of winter wheat in the north china plain. Irrig. Sci. 31, 1025-1037.

Wang, Q., F. Li, E. Zhang, G. Li, and M. Vance. 2012. The effects of irrigation and nitrogen application rates on yield of spring wheat (longfu-920), and water use efficiency and nitrate nitrogen accumulation in soil. AJCS 6(4):662-672.

$\mathrm{Yu}, \mathrm{S}$. H .I. and Y. U. Zhenwen. 2008. Effects of nitrogen ferti- lizer rates and ratios of base and topdressing on wheat yield, soil nitrate content and nitrogen balance. Front. Agric. China 2(2): 181-189.

Yue, S.C, Z.W. Yu and S.L. Yu. 1998. Effect of nitrogen application at different growth stages on nitrogen distribution and leaves metabolism in winter wheat. Acta Agronomica Sinica, 24(5): 1-4.

Zaki, N.M., M. A. Gomaa, F. I. Radwan, M. S. Hassanein and A. M. Wali. 2012. Effect of mineral organic and bio-fertilizer on yield, yield components and chemical composition of some wheat cultivars J. of applied Sci., Res. 8(1) 174-191.

Zhang, F., J. Niu, W. Zhang, X. Chen, C. Li, L. Yuan, and J. Xie. 2010. Potassium Nutrition of Crops under Varied Regimes of Nitrogen Supply. Plant and Soil 335:21-34.

Zhang, F., S. Kang, J. Zhang, R. Zhang and F. Li. 2004. Nitrogen Fertilization on Uptake of Soil Inorganic Phosphorus Fractions in the Wheat Root Zone. Soil Sci. Soc. Am. J. 68:1890-1895. Zhang, Q. Q., H. L. Xu , Z. L. Fan, M. Ye, P. J. Yu and J. Y. Fu. 2013. Impact of Implementation of Large-Scale Drip Irrigation in Arid and Semi-arid Areas: Case Study of Man as River Valley, Communications in Soil Science and Plant Analysis, 44(13): 2064-2075. DOI: $10.1080 / 0010$ 3624.2013.783055.

Zhu, J.H., X.L Li, P. Christie, and J.L. Li. 2005. Environmental implications of low nitrogen use 
efficiency in excessively fertilized hot pepper (Capsicum frutescens L.) cropping systems.
Agric. Eco syst. Environ. 111: 70-80. 


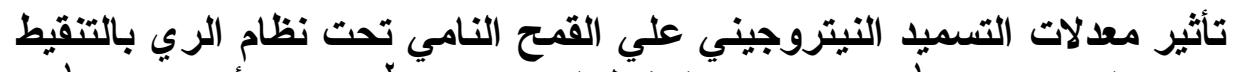



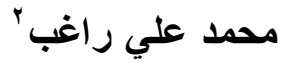

$$
\begin{aligned}
& \text { 'قسم الأر اضي و المياه - كلية الزر اعة - جامعة الأزهر - أسيوط - مصر - مصر }
\end{aligned}
$$

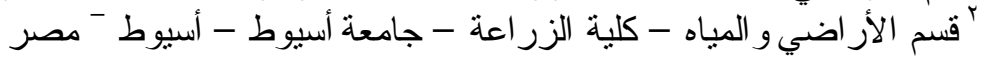

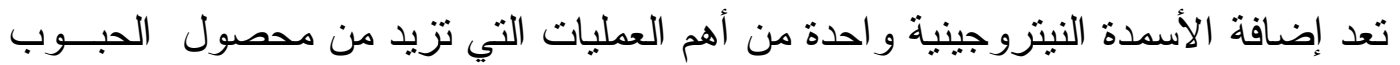

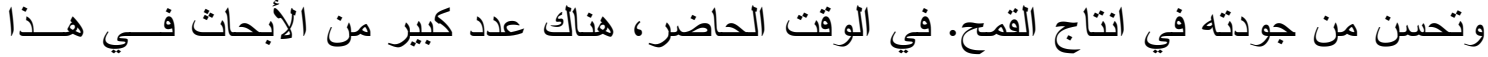

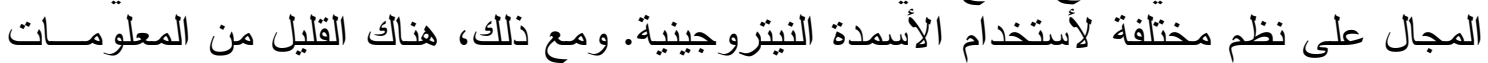

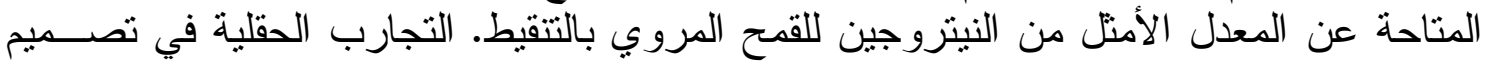

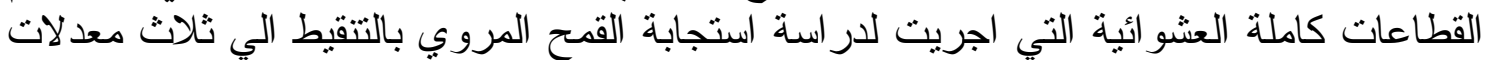

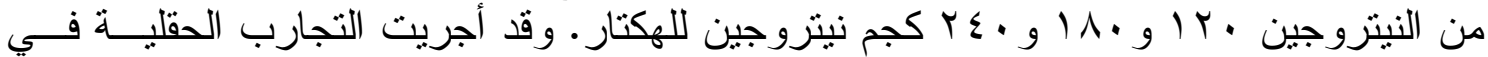

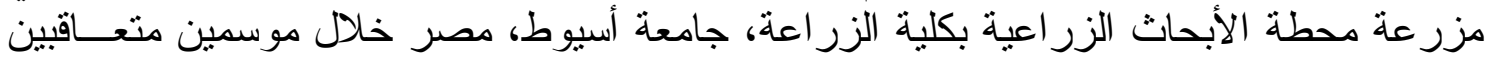

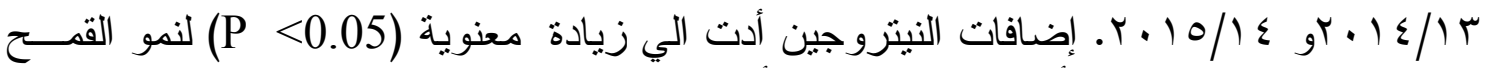

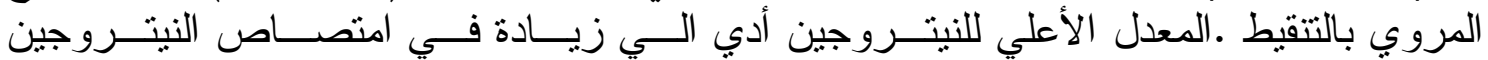

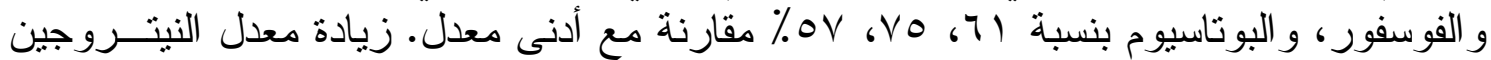

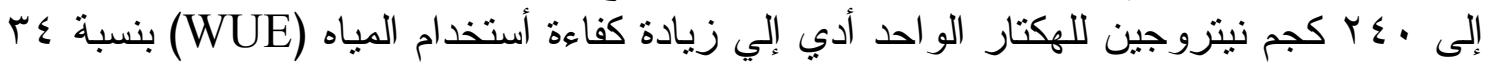

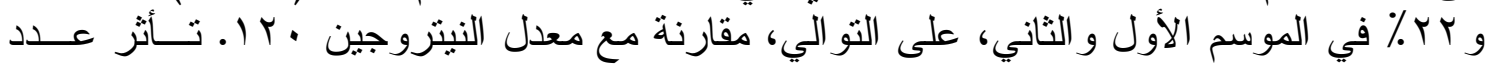

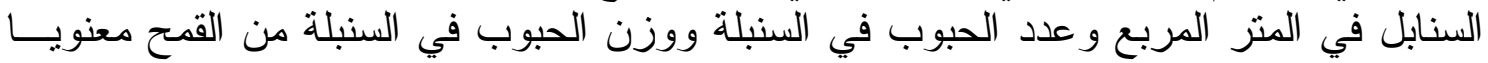

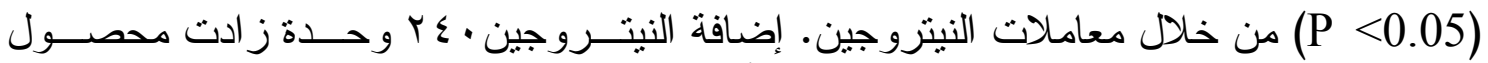

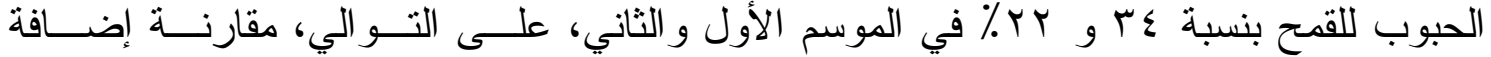

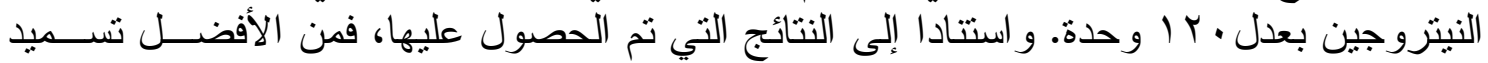

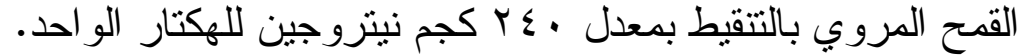

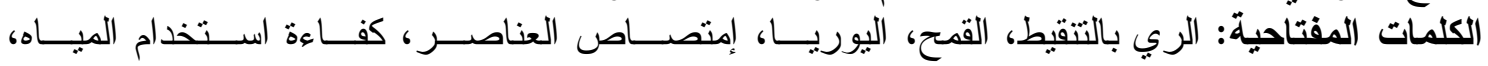

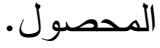

